\title{
Reply to Henningsen et al.
}

\author{
Citation for published version (APA):
}

Rief, W., Korwisi, B., Nicholas, M., Vlaeyen, J. W. S., Smith, B. H., First, M. B., Kosek, E., Barke, A., \& Treede, R-D. (2019). Reply to Henningsen et al. Chronic primary pain : a pain-centered view of the world is too narrow. Pain, 160(7), 1683-1685. https://doi.org/10.1097/j.pain.0000000000001564

Document status and date:

Published: 01/07/2019

DOI:

10.1097/j.pain.0000000000001564

Document Version:

Publisher's PDF, also known as Version of record

Document license:
Taverne

\section{Please check the document version of this publication:}

- A submitted manuscript is the version of the article upon submission and before peer-review. There can be important differences between the submitted version and the official published version of record.

People interested in the research are advised to contact the author for the final version of the publication, or visit the DOI to the publisher's website.

- The final author version and the galley proof are versions of the publication after peer review.

- The final published version features the final layout of the paper including the volume, issue and page numbers.

Link to publication

\footnotetext{
General rights rights.

- You may freely distribute the URL identifying the publication in the public portal. please follow below link for the End User Agreement:

www.umlib.nl/taverne-license

Take down policy

If you believe that this document breaches copyright please contact us at:

repository@maastrichtuniversity.nl

providing details and we will investigate your claim.
}

Copyright and moral rights for the publications made accessible in the public portal are retained by the authors and/or other copyright owners and it is a condition of accessing publications that users recognise and abide by the legal requirements associated with these

- Users may download and print one copy of any publication from the public portal for the purpose of private study or research.

- You may not further distribute the material or use it for any profit-making activity or commercial gain

If the publication is distributed under the terms of Article $25 \mathrm{fa}$ of the Dutch Copyright Act, indicated by the "Taverne" license above, 
Philipps-University Marburg, Marburg, Germany Marburg, Germany

${ }^{\circ}$ Centre for Neuroscience, Surgery and Trauma,

Blizard Institute,

Wingate Institute of Neurogastroenterology, Barts and The London School of Medicine and Dentistry, Queen Mary, University of London, London, United Kingdom ${ }^{d}$ Department of Medicine and Science of Aging, CeSI-MeT, G D’Annunzio University of Chieti, Chieti, Italy ${ }^{e}$ Division of Clinical and Biological Psychology, Department of Psychology, Catholic University of Eichstätt-Ingolstadt, Eichstätt, Germany E-mail address: Rolf-Detlef.Treede@medma.uni-heidelberg.de (R.-D. Treede) http://dx.doi.org/10.1097/j.pain.0000000000001558

\section{Chronic primary pain: a pain-centered view of the world is too narrow}

\section{Letter to Editor:}

We read with interest the IASP classification of chronic primary pain for ICD-11. ${ }^{5}$ It has been notoriously difficult to classify the symptoms of patients who suffer from chronic bodily distress such as pain. The new IASP proposal for ICD-11 is an important step forward: It secures a space in the classification that is neutral concerning the misleading dichotomy of somatic vs mental disorders, and in the definition of chronic primary pain, it includes emotional distress and functional disability as important components. However, the focus on pain only is a major disadvantage of this proposal. Although pain is the most frequent, it is by no means the only bodily symptom for which the characteristics developed in the proposal apply: patients with dizziness, palpitations, indigestion, numbness, motor disturbances, and many other symptoms that often also occur together with chronic pain ${ }^{2-4}$ are in need of an improved classification as well. Even if chronic pain is one major symptom in some of the so-called primary pain syndromes such as fibromyalgia syndrome and irritable bowel syndrome, some of these patients suffer more from fatigue than from pain. ${ }^{1,3} \mathrm{~A}$ paincentered view on somatic syndromes is therefore not appropriate.

In addition, the chronic pain proposal is not well aligned with the suggestions for bodily distress disorder and bodily stress syndrome in other parts of $I C D-11 .{ }^{6}$ Hence, the fact that nonpain symptoms are left out by the IASP proposal unfortunately carries the risk of increasing separations and confusions in $/ C D-11$.

In addition, the authors claim that the term "functional" is ambiguous. ${ }^{5}$ However, the term "functional disorders" is well established in gastroenterology, eg, in the Rome criteria for functional gastrointestinal disorders ${ }^{7}$ and should not be relinquished until a better term has been broadly accepted.

We agree with the IASP working group for $I C D-11$ that the new version of the International Classification of Diseases should be easily applicable in primary care as well as improve accurate epidemiological investigations and characterization of patients for clinical studies. ${ }^{8}$ IASP cannot reach these goals single-handedly. A collaboration with other associations (general medicine, gastroenterology, psychiatry, and psychosomatic medicine) is necessary.

\section{Conflict of interest statement}

The authors have no conflict of interest to declare.

\section{References}

[1] Clauw DJ, D’Arcy Y, Gebke K, Semel D, Pauer L, Jones KD. Normalizing fibromyalgia as a chronic illness. Postgrad Med 2018;130:9-18.

[2] Fink P, Toft T, Hansen MS, Ombol E, Olesen F. Symptoms and syndromes of bodily distress: an exploratory study of 978 internal medical, neurological, and primary care patients. Psychosom Med 2007;69:30-9.

[3] Frändemark $\AA$, Jakobsson Ung E, Törnblom H, Simrén M, Jakobsson S. Fatigue: a distressing symptom for patients with irritable bowel syndrome. Neurogastroenterol Motil 2017;29.

[4] Häuser W, Wolfe F, Henningsen P, Schmutzer G, Brähler E, Hinz A. Untying chronic pain: prevalence and societal burden of chronic pain stages in the general population-a cross-sectional survey. BMC Public Health 2014;14:352.

[5] Nicholas M, Vlaeyen JWS, Rief W, Barke A, Aziz Q, Benoliel R, Cohen M, Evers S, Giamberardino MA, Goebel A, Korwisi B, Perrot S, Svensson P, Wang SJ, Treede RD; IASP Taskforce for the Classification of Chronic Pain. The IASP classification of chronic pain for ICD-11: chronic primary pain. PAIN 2019;160:28-37.

[6] Reed GM, First MB, Kogan CS, Hyman SE, Gureje O, Gaebel W, Maj M, Stein DJ, Maercker A, Tyrer P, Claudino A, Garralda E, Salvador-Carulla L, Ray R, Saunders JB, Dua T, Poznyak V, Medina-Mora ME, Pike KM, AyusoMateos JL, Kanba S, Keeley JW, Khoury B, Krasnov VN, Kulygina M, Lovell AM, de Jesus Mari J, Maruta T, Matsumoto C, Rebello TJ, Roberts MC, Robles R, Sharan P, Zhao M, Jablensky A, Udomratn P, Rahimi-Movaghar A, Rydelius PA, Bährer-Kohler S, Watts AD, Saxena S. Innovations and changes in the ICD-11 classification of mental, behavioural and neurodevelopmental disorders. World Psychiatry 2019;18:3-19.

[7] Tack J, Drossman DA. What's new in Rome IV? Neurogastroenterol Motil 2017;29.

[8] Treede RD, Rief W, Barke A, Aziz Q, Bennett MI, Benoliel R, Cohen M, Evers S, Finnerup NB, First MB, Giamberardino MA, Kaasa S, Korwisi B, Kosek E, Lavand'homme P, Nicholas M, Perrot S, Scholz J, Schug S, Smith BH, Svensson P, Vlaeyen JWS, Wang SJ. Chronic pain as a symptom or a disease: the IASP classification of chronic pain for the International Classification of Diseases (ICD-11). PAIN 2019;160:19-27.

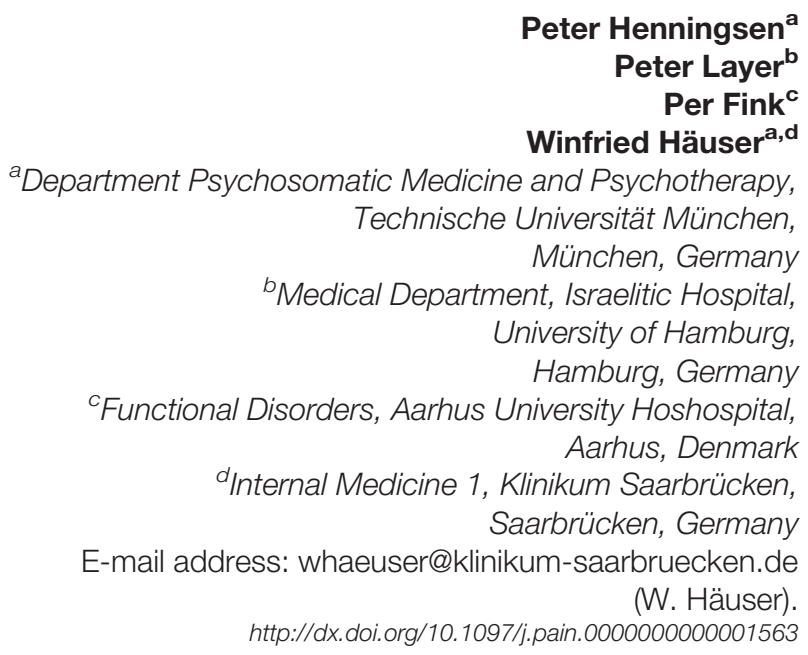

\section{Reply to Henningsen et al.}

\section{Letter to Editor:}

We are grateful for the positive evaluation of our classification proposal on chronic pain disorders of Henningsen et al., ${ }^{4}$ confirming that this is an important step forward and avoiding any artificial dichotomy of somatic vs mental disorders. However, the authors were concerned that we focused only on pain and overlooked the frequent overlap of pain symptoms with other bodily complaints, and that we did not harmonize our proposal with the new suggestions of "bodily distress disorder" in the psychiatric part of the ICD-11 draft or with other "functional syndromes". ${ }^{4}$ 
Indeed, we aimed to improve the classification of chronic pain conditions, but not to solve all classification problems in the large field of what are often referred to as "medically unexplained symptoms". " Many "functional disorders" are poorly defined, distributed over different categories of medical specialties, and use different frameworks for classifying these disorders. We strongly encourage the authors, all of them being acknowledged experts of psychosomatic medicine, to further advance the classification of the various functional somatic syndromes in medicine. If a comprehensive classification system for functional syndromes exists, we will be delighted to harmonize our proposal with it. However, we are currently not aware of such a comprehensive classification system of functional disorders, but only of specialized approaches (such as the ROME criteria in gastroenterology $\left.{ }^{3}\right)$.

Internationally, chronic pain conditions have been found to be among the most disabling medical conditions, ${ }^{2,7}$ and arguably, the widely recognised shortcomings of both $/ C D-10$ and DSM-5 in the diagnosis of chronic pain have contributed to the suboptimal identification and treatment of these conditions. ${ }^{9}$ If various biopsychosocial influences are identified, and the chronic pain condition is not better accounted for by another primary medical condition, we recommend to use the diagnosis of "chronic primary pain". ${ }^{5}$ We do not recommend that this should be considered a mental disorder, such as the recently suggested "bodily distress disorder" mentioned by the authors, ${ }^{4}$ because chronic pain is not a mental disorder, although it often has mental disorders, such as depression, as comorbidities. Moreover, we are very confident that chronic primary pain as a term will be highly acceptable to patients, pain experts, but also in general medicine. The initial data from field trials and surveys in patient health groups confirm this assumption. ${ }^{1}$ The German predecessor of the chronic primary pain diagnosis, "chronic pain with somatic and psychological factors," became one of the most frequently used diagnoses in tertiary care in Germany after its introduction ${ }^{6}$ and was far more frequently used than "bodily distress disorder" or any of its precursors, further underlining the high acceptability of this development. However, we agree with Henningsen et al. ${ }^{4}$ that many patients with chronic pain symptoms suffer from additional somatic complaints. We would contend that these are acknowledged in the different subtypes of chronic primary pain, ${ }^{5}$ and multiple parenting can be applied. ${ }^{9,11}$ Such overlaps are typical for many medical and psychiatric conditions, and are not unique for pain. After the rationale of $I C D-11,{ }^{10,11}$ this should be addressed using comorbidity diagnoses, until future classification systems address the issue of overlapping syndromes better than is currently the case.

Finally, in reference to the authors' contention that IASP could not achieve the stated goals by itself and that we should be collaborating with other associations, ${ }^{4}$ we want to bring to the authors' attention the fact that our classification proposal of chronic pain syndromes was developed by a large multidisciplinary expert group that included clinicians and researchers from various medical specialties (eg, rheumatology, neurology, pain medicine, and primary $\left.\operatorname{care}^{8}\right)$, dentistry, and psychology. Nevertheless, continuing this interdisciplinary perspective, we are looking forward to further improving our proposal through collaborations with other expert groups.

\section{Conflict of interest statement}

A. Barke reports personal fees from International Association for the Study of Pain during the conduct of the study. M. First reports personal fees from Lundbeck International Neuroscience Foundation, outside the submitted work. R.-D. Treede reports grants from Boehringer Ingelheim, Astellas, AbbVie, Bayer, personal fees from Astellas, Grünenthal, Bauerfeind, Hydra, Bayer, grants from EU, DFG, BMBF, outside the submitted work. The remaining authors have no conflicts of interest to declare.

\section{References}

[1] Barke A, Korwisi B, Casser HR, Fors EA, Geber C, Schug S, Stubhaug A, Ushida T, Wetterling T, Rief W, Treede RD. Pilot field testing of the chronic pain classification for ICD-11: the results of ecological coding. BMC Public Health 2018;18:1239.

[2] Blyth FM, Briggs AM, Huckel Schneider C, Hoy DG, March LM. The global burden of musculoskeletal pain-where to go from here? Am J Public Health 2019;109:35-40.

[3] Drossman DA, Hasler WL. Rome IV-functional GI disorders: disorders of gut-brain interaction. Gastroenterology 2016;150:1257-61.

[4] Henningsen P, Layer P, Fink P, Häuser W. Chronic primary pain: a paincentered view of the world is too narrow. PAIN 2019;160:1683.

[5] Nicholas M, Vlaeyen JWS, Rief W, Barke A, Aziz Q, Benoliel R, Cohen M, Evers S, Giamberardino MA, Göbel A, Korwisi B, Perrot S, Svensson P, Wang SJ, Treede RD. The IASP Taskforce for the Classification of Chronic Pain. The IASP classification of chronic pain for ICD-11: chronic primary pain. PAIN 2019;160:28-37.

[6] Nilges P, Rief W, Kaiser U, Lutz J, Pfingsten M, Arnold B. Diagnosis F45 is scientifically reliable. Schmerz 2018;32:213-15.

[7] Rice ASC, Smith BH, Blyth FM. Pain and the global burden of disease. PAIN 2016;157:791-6.

[8] Smith BH, Fors EA, Korwisi B, Barke A, Cameron P, Colvin L, Richardson C, Rief W, Treede RD; The IASP Taskforce for the Classification of Chronic Pain. The IASP classification of chronic pain for ICD-11: applicability in primary care. PAIN 2019;160:83-7.

[9] Treede RD, Rief W, Barke A, Aziz Q, Bennett MI, Benoliel R, Cohen M, Evers S, Finnerup NB, First MB, Giamberardino MA, Kaasa S, Korwisi B, Kosek E, Lavand'homme P, Nicholas M, Perrot S, Scholz J, Schug S, Smith BH, Svensson P, Vlaeyen JWS, Wang SJ. Chronic pain as a symptom or a disease: the IASP classification of chronic pain for the international classification of diseases (ICD-11). PAIN 2019;160: 19-27.

[10] World Health Organization. Frozen version of ICD-11 for preparing implementation. 2018. Available at: https://icd.who.int/browse11/l-m/ en/. Accessed March 4, 2019.

[11] World Health Organization. ICD-11 International Classification of Diseases for Mortality and Morbidity Statistics. Eleventh Revision. Reference Guide. Geneva: WHO, 2019. Available at: https://icd.who. int/icd11refguide/en/index.html. Accessed March 4, 2019.

\section{Winfried Rief ${ }^{a}$ Beatrice Korwisi ${ }^{\mathrm{a}}$ Michael Nicholas ${ }^{b}$ Johan W.S. Vlaeyen ${ }^{\mathrm{c}, \mathrm{d}, \mathrm{e}}$ Blair H. Smith ${ }^{\dagger}$ Michael B. First ${ }^{\mathrm{g}}$ Eva Kosek ${ }^{\mathrm{h}}$ Antonia Barke ${ }^{i}$ Rolf-Detlef Treede ${ }^{\mathrm{j}}$ Marburg University Marburg, Germany Royal North Shore Hospital University of Sydney Sydney, Australia University of Leuven Leuven, Belgium Maastricht University Maastricht, the Netherlands}

${ }^{a}$ Department of Clinical Psychology and Psychotherapy ${ }^{b}$ Pain Management Research Institute ${ }^{c}$ Research Group Health Psychology ${ }^{d}$ Department of Clinical Psychological Science 
'TRACE,

Center for Translational Health Research KU Leuven-Ziekenhuis Oost-Limburg, Genk, Belgium ${ }^{f}$ Division of Population Health and Genomics School of Medicine University of Dundee Dundee, Scotland ${ }^{9}$ Department of Psychiatry Columbia University New York State Psychiatric Institute New York, NY, United States
${ }^{h}$ Department of Clinical Neuroscience Karolinska Institutet Stockholm, Sweden

${ }^{i}$ Catholic University of Eichstätt-Ingolstadt Department of Clinical and Biological Psychology Eichstätt, Germany

jDepartment of Neurophysiology, Center for Biomedicine and Medical Technology Mannheim (CBTM) Medical Faculty Mannheim of Heidelberg University Mannheim, Germany

E-mail address: rief@uni-marburg.de (W. Rief) http://dx.doi.org/10.1097/j.pain.0000000000001564 